\title{
Rhizodeposition of nitrogen by red clover, white clover and ryegrass leys
}

\author{
H. Høgh-Jensen*, J.K. Schjoerring \\ Department of Agricultural Sciences, Royal Veterinary and Agricultural University, Agrovej 10, DK-2630 Taastrup, Denmark
}

Received 4 April 2000; received in revised form 10 July 2000; accepted 29 July 2000

\begin{abstract}
Correct assessment of the rhizodeposition of $\mathrm{N}$ in grassland is essential for the evaluation of biological $\mathrm{N}_{2}$-fixation of legumes, for the total $\mathrm{N}$ balance of agro-ecosystems, and for the pre-cropping value of grasslands. Using a leaf-feeding technique by which plants were ${ }^{15} \mathrm{~N}$ labelled while growing in mezotrons in the field, the rhizodeposition of $\mathrm{N}$ by unfertilised red clover, white clover and perennial ryegrass growing in pure stands was shown to amount to 64,71 and $9 \mathrm{~g} \mathrm{~N} \mathrm{~m}^{-2}$, respectively, over two complete growing seasons. The corresponding values for red clover and white clover growing in mixtures with ryegrass were 89 and $32 \mathrm{~g} \mathrm{~N} \mathrm{~m}^{-2}$, respectively. The rhizodeposited $\mathrm{N}$ compounds, including fine roots, constituted more than $80 \%$ of the total plant-derived $\mathrm{N}$ in the soil, and in all cases exceeded the amount of $\mathrm{N}$ present in stubble. In the mixtures of red clover-ryegrass and white clover-ryegrass and the pure stands of red clover, white clover and ryegrass, respectively, the rhizodeposition constituted a 1.05, 1.52, 1.26, 2.21 and 2.77 fold increase over the total $\mathrm{N}$ in the shoots harvested during the two production years. In pure stands and mixtures of clover, 84 and $92 \%$, respectively, of this $\mathrm{N}$ derived from biological $\mathrm{N}_{2}$ fixation. It is concluded that rhizodeposition provides a very substantial input of $\mathrm{N}$ to the legume-based grassland systems with great consequences for ecosystem $\mathrm{N}$ balance and turnover. Furthermore, the amount of atmospheric-derived $\mathrm{N}$ in the rhizodeposits may exceed that in the harvested shoots. (C) 2001 Elsevier Science Ltd. All rights reserved.
\end{abstract}

Keywords: Pasture; Red clover; Rhizodeposition; Roots; Ryegrass; White clover

\section{Introduction}

In legume-based leys knowledge about the below-ground $\mathrm{N}$ pools are important for correct estimates of the total biological $\mathrm{N}_{2}$-fixation as well as for the potential $\mathrm{N}$ supply to the succeeding crops. The below-ground $\mathrm{N}$ pools can be divided into visible fibrous macro roots and in rhizodeposits that contain the rest. Rhizodeposition may contain many different organic compounds including water-soluble exudates, sloughed-off root tissue and dead roots (Rovira et al., 1979). The rhizodeposition of carbon can be very substantial, exceeding that present as fibrous roots at the end of the growing season by more than $20-50 \%$ (Whipps and Lynch, 1985; Cheng et al., 1993). Additionally substantial amounts of $\mathrm{N}$ can be deposited together with the carbon (Curl and Truelove, 1986; Janzen, 1990; Janzen and Bruinsma, 1993). The deposited compounds have major effects on the density and activity of microorganisms in the rhizosphere and, hence, on the turnover and plant availability of nutrients in the root zone. After mineralisation, the nutrients contained in the rhizodeposited compounds will be

\footnotetext{
* Corresponding author. Tel.: +45-3528-3391; fax: +45-3528-3460.

E-mail address: hhj@kvl.dk (H. Høgh-Jensen).
}

subject to plant or microbial uptake, adsorption on soil particles or lost from the plant-soil system. Consequently, rhizodeposition will always be measured as the net outcome of several interacting processes.

Deposition of plant-derived $\mathrm{N}$, including rhizodeposits and litter fall, under field conditions is largely unknown for the common grassland species. Using a direct ${ }^{15} \mathrm{~N}$-labelling technique McNeill et al. (1997) conducted an experiment with pasture legumes growing in relatively small pots under controlled conditions. Under these conditions, rhizodeposition constituted $17-24 \%$ of the total below-ground clover-N. These values agree with the estimates obtained by the use of comparable ${ }^{15} \mathrm{~N}$-labelling techniques for pea in pot experiments (Sawatsky and Soper, 1991; Jensen, 1996), alfalfa in solution culture (Ta et al., 1979), and field bean and soybean in a pot study (Ruschel et al., 1979). Others found that rhizodeposition of $\mathrm{N}$ from alfalfa were insignificant under both field and controlled conditions (Lory et al., 1992). Importantly, all these studies are based on pure stands of the specific species. There is a particular need for measurements of rhizodeposition under field conditions by mixtures of common grassland species.

Isolation of mature root material from soil by wet sieving is commonly used in connection with the assessment of root 
biomass (Böhm, 1979). However, this procedure only partly recovers fine roots as well as partly or fully decomposed root material (Sauerbeck and Johnen, 1976; Unkovich et al., 1994). Such partial recoveries obviously make predictions of $\mathrm{N}$ mineralisation difficult in a crop rotational context (Høgh-Jensen and Schjoerring, 1997; Høgh-Jensen 1999). A more direct determination of the below-ground plantderived $\mathrm{N}$ pools and the subsequent turnover of plantderived organic $\mathrm{N}$ during the growing period requires ${ }^{15} \mathrm{~N}$ labelling of the plants (Hood et al., 1999). The labelling technique must uniformly incorporate ${ }^{15} \mathrm{~N}$ in tissues and organs. Ledgard et al. (1985) and Ta et al. (1989) labelled legumes by immersing single trifoliate leaves into a $\mathrm{K}^{15} \mathrm{NO}_{3}$ solution. Recently, urea has been used to feed individual plants or leaves (Palta et al., 1991; Russell and Fillery, 1996a; McNeill et al., 1997). This technique enables the labelling of individual plants grown in close association with other species under field conditions.

Our purpose was to quantify the contribution of actively $\mathrm{N}_{2}$-fixing red clover and white clover grown in either of the mixtures with perennial ryegrass or in pure stands to the below-ground $\mathrm{N}$ pools following a 2-year production period, and to quantify the proportion of these below-ground $\mathrm{N}$ pools that was derived from the fixation of atmospheric $\mathrm{N}$. A direct technique in which ${ }^{15} \mathrm{~N}$-labelled nitrogen was fed to the leaves of either clover or grass plants growing in fieldbased mezotrons (PVC-cylinders, internal diameter $29.7 \mathrm{~cm}$, depth $60 \mathrm{~cm}$ ) was used to label the rhizodeposited compounds. At the end of the two production years, the mezotrons were excavated, followed by an analysis of the

${ }^{15} \mathrm{~N}$, total- $\mathrm{N}$ and total-C in macro roots, rhizosphere soil including fine roots, bulk soil, stubble and above-ground plant parts.

\section{Materials and methods}

The experimental area was located $18 \mathrm{~km}$ west of Copenhagen $\left(55^{\circ} 40^{\prime} \mathrm{N}, 12^{\circ} 18^{\prime} \mathrm{E} ; 28 \mathrm{~m}\right.$ above MSL; mean annual precipitation $600 \mathrm{~mm}$; growth period of 210 days) in a field that had been cropped mainly with cereals for the last 30 years without any organic residue or any phosphorus or potassium application. The experimental area was selected because of its history to obtain an agricultural soil depleted in fertility with a low soil microbial biomass pool and little amounts of particulate organic matter. Such circumstances are expected to represent conditions where rhizodeposition will be of greatest significance to agricultural systems.

Following its cropping history, the total-N content of the soil was on an average low, that is $0.133,0.048,0.059,0.050$ and $0.040 \%$ at the depths of $0-20,20-40,40-60,60-80$ and $80-100 \mathrm{~cm}$, respectively. Furthermore, the $\mathrm{C}$-to-N ratio was less than 9 in all depths. In the upper $40 \mathrm{~cm}$ soil, the $\mathrm{NaHCO}_{3}$-soluble $\mathrm{P}$ content of the soil (Olsen et al., 1954; $0.5 \mathrm{~g}$ dry soil, $10 \mathrm{ml} 0.5 \mathrm{M} \mathrm{NaHCO}_{3}$ shaken for $24 \mathrm{~h}$ ) determined spectrophotometrically was $10.8 \mathrm{mg} \mathrm{P} \mathrm{kg}^{-1}$ dry soil, the $\mathrm{NH}_{4}$-acetate extractable content (Page et al., 1982; $10 \mathrm{~g}$ dry soil, $100 \mathrm{ml} 0.5 \mathrm{M} \mathrm{NH}_{4}$-acetate $+3 \mathrm{mM} \mathrm{LiCl}$ shaken for $45 \mathrm{~min}$, stand overnight) was $70 \mathrm{mg} \mathrm{K}, 38 \mathrm{mg} \mathrm{Mg}$, $9 \mathrm{mg} \mathrm{Na}$, and $1047 \mathrm{mg} \mathrm{Ca} \mathrm{kg}^{-1}$ dry soil. The soil $\mathrm{pH}_{(0.01 \mathrm{M}}$ CaCl) was 5.1.

The soil had 13.2, 14.9 and $22.6 \%$ clay, $17.5,18.1$ and $21.7 \%$ silt, $39.2,36.2$, and $34.8 \%$ fine sand and $30.1,30.8$ and $20.9 \%$ coarse sand at the depths of 10-25, 40-45 and $80-85 \mathrm{~cm}$, respectively, as determined used the hydrometer method (Gee and Bauder, 1986).

\subsection{Establishing the plant communities and experimental treatments}

The experimental plant communities were established in spring 1997. Ley seed mixtures were undersown in an unfertilised spring barley crop in plots of $15 \mathrm{~m}^{2}$ sizes, four replicates. The ley mixtures were established by seeding $10 \mathrm{~kg}$ seed ha ${ }^{-1}$ of white clover (Trifolium repens L. cv. Milkanova) or red clover (Trifolium pratense L. cv. Rajah) in mixture with $20 \mathrm{~kg} \mathrm{seed} \mathrm{ha}^{-1}$ of perennial ryegrass (Lolium perenne L. cvs. Tetramax and Borvi). Following a factorial experimental design, ryegrass in pure stand was established by seeding $25 \mathrm{~kg}$ seed ha ${ }^{-1}$ and white or red clover in pure stand by seeding $10 \mathrm{~kg}$ seeds $\mathrm{ha}^{-1}$. The barley crop was harvested in August and the developing ley received no further treatment before the following spring except for defoliation in late autumn.

In the developing ley, during late autumn 1997, PVC cylinders with an internal diameter of $29.7 \mathrm{~cm}$ were inserted $60 \mathrm{~cm}$ into the ground leaving $5 \mathrm{~cm}$ above-ground. These cylinders are subsequently termed mezotrons. One mezotron were inserted per plot of pure stands and two in mixtures. Hence, four replicates were inserted in pure stands of ryegrass, pure stands of white clover and pure stands of red clover and eight replicates in mixtures of ryegrass-white clover and ryegrass-red clover. The mixtures were ${ }^{15} \mathrm{~N}$ cross-labelled, i.e. either the clover component or the grass component was ${ }^{15} \mathrm{~N}$ labelled.

The plant communities received no other treatment but the sward was cut four times during the first growing season and three times during the second growing season. At the end of the second growing season, after the final harvest, the mezotrons were excavated and sampled as described below.

\subsection{Leaf labelling}

One clover trifoliate leaf and two-four grass leaves, depending on leaf size, were each inserted into $2 \mathrm{ml}$ micro-centrifuge vials containing $1.0 \mathrm{ml}$ of a $0.5 \%(\mathrm{v} / \mathrm{v})$ urea (99 at.\%) (McNeill et al., 1997). The vial was then sealed using an inert plastic material $\left(\right.$ Terostat ${ }^{\circledR}$, Henkel Surface Technologies, PA, USA) to avoid ${ }^{15} \mathrm{~N}$ losses from the solution. Each time the leaves were selected from differing plants and enclosed in the vials between 2 and 7 days, depending on the climatic conditions. The grass was labelled three times between each harvest, except between 
the third and fourth harvest, resulting in a total of nine vials between each harvest. This gave a total of 27 vials in each cylinder in both growing seasons. The clover was labelled 3-5 times between each harvest. This gave a total of 9-15 vials between each harvest, resulting in a total of 40 vials in the first and 33 vials in the second growing season. In the mixtures, a cross-labelling procedure was followed so that either the ryegrass or the clovers was labelled.

At the end of each labelling period, the vials were removed and the residual solution was analysed for $\mathrm{N}$ and ${ }^{15} \mathrm{~N}$ content, as described below, in order to precisely determine plant uptake of ${ }^{15} \mathrm{~N}$. The uptake was calculated as the amount of ${ }^{15} \mathrm{~N}$ offered to the plants subtracted the amount that was left in the vials at the end of each labelling period. The amounts of $\mathrm{N}$ added annually to the system this way was equivalent to $0.5-1.0 \mathrm{~g} \mathrm{~N} \mathrm{~m}^{-2}$.

\subsection{Biological $\mathrm{N}_{2}$ fixation and dry matter production}

Adjacent to the mezotrons, $2-\mathrm{m}^{2}$ plots with the same plant communities as those enclosed in the mezotron were labelled with ${ }^{15} \mathrm{~N}$ fertiliser [ $\left(\mathrm{NH}_{4}\right)_{2} \mathrm{SO}_{4} ; 99$ at.\%; equivalent to $0.22 \mathrm{~g} \mathrm{~N} \mathrm{~m}^{-2}$ ] (described in detail by Høgh-Jensen and Schjoerring, 2000) to determine symbiotic $\mathrm{N}_{2}$-fixation, using grass in pure stand as the reference. The plant populations in the ${ }^{15} \mathrm{~N}$ labelled plots and in the PVC-mezotrons were managed similarly. Yields of dry matter and $\mathrm{N}$ accumulation was determined on the basis of these $2-\mathrm{m}^{2}$ plots.

\subsection{Sampling}

The last harvest took place late October in the second growing season leaving a stubble height of $5 \mathrm{~cm}$. All PVC-mezotrons were excavated early November when the soil temperature had decrease below $5^{\circ} \mathrm{C}$. The soil column within each mezotron was gently allowed to slide out. Then the stubble material was cut at the soil surface, separated into grass and clover, dried to constant weight at $80^{\circ} \mathrm{C}$, weighed, pulverised to a fine powder and analysed. The time from excavation to isolation of the roots from the soil was less than three weeks, during which the intact mezotrons were kept at $5^{\circ} \mathrm{C}$.

The intact soil columns were cut into sections of $0-10$, 10-20, 20-40 and 40-60 cm depth. Each section was weighed and all visual roots were subsequently removed manually together with the adhering soil. This root material was dried at $80^{\circ} \mathrm{C}$ to constant weight. Subsequently, soil that had been adhering to the fresh roots was easily separated from the dry roots and termed the rhizosphere soil. The total mass of rhizosphere soil in white clover-ryegrass mixtures and ryegrass in pure stands amounted to approx. $1.5 \%$ and did not exceed $0.5 \%$ of total soil in the other plant communities. More soil remained on the macro roots in the upper $10 \mathrm{~cm}$ soil layer compared to roots in deeper soil layers. Relating the amount of dry soil in the mezotrons after root removal to the volume of $0-10,10-20,20-40$ and 40$60 \mathrm{~cm}$ depth, respectively, gave average soil densities of
2.0, 2.3, 1.4 and $1.4 \mathrm{~g} \mathrm{~cm}^{-3}$, respectively. This indicates small inaccuracies in determining section sizes during the slicing of soil columns.

The root material and the rhizosphere soil were finely pulverised and analysed for ${ }^{15} \mathrm{~N}$, total $\mathrm{N}$ and $\mathrm{C}$ content. A representative sample of the bulk soil was dried to determine the dry matter content of the bulk soil. This sample was sieved $(2 \mathrm{~mm})$ and analysed for ${ }^{15} \mathrm{~N}$, total-N and totalC. Soil adhering to the stubble and other plant debris on the soil surface were pulverised together with the organic matter. The dry matter contents were subsequently normalised to a $\mathrm{C}$ content of $43 \%$. This correction affects only the reported dry matter yields, and not the estimates of $\mathrm{N}$ rhizodeposition.

The plant and soil materials were analysed for ${ }^{15} \mathrm{~N}$, total$\mathrm{N}$ and total-C using the Dumas dry combustion method in a system consisting of an ANCA-SL Elemental Analyser coupled to a 20-20 Tracermass Mass Spectrometer (Europa Scientific Ltd. Creve, UK). Analytical SE for ${ }^{15} \mathrm{~N}$ was $0.015 \%$.

\subsection{Proportion of absorbed ${ }^{15} N$ in the living plant material, in rhizosphere and in bulk soil}

${ }^{15} \mathrm{~N}$ recovery in the living plant material was calculated as the sum of the ${ }^{15} \mathrm{~N}$ content in shoots, stubble material at the final sampling time, and macro roots.

Assuming the deposited $\mathrm{N}$ to have the same ${ }^{15} \mathrm{~N}$ enrichment as the sampled macro root $\mathrm{N}$, the rhizodeposition relative to total-N in the bulk soil and in the rhizosphere soil was calculated as described by Janzen and Bruinsma (1989) using the following equation:

$\% \mathrm{Ndfr}=\left[\right.$ at. $\%{ }^{15} \mathrm{~N}$ excess (soil) $/$ at. $\%{ }^{15} \mathrm{~N}$ excess (roots) $] \times 100$

where the at.\%-excess of the roots was taken as the enrichment of the macro roots relative to 0.3663 which is the enrichment of atmospheric $\mathrm{N}_{2}$. As the roots of the mixtures were not separated, the at.\%-excess of the species in pure stands was used for calculations. The at.\%-excess of the soil was taken as the enrichment of the soil relative to 0.3708 at. $\%$, which was the average natural enrichment of ryegrass growing under unlabelled field conditions.

Potential losses of ${ }^{15} \mathrm{~N}$ during the labelling period was estimated by calculating the total ${ }^{15} \mathrm{~N}$ absorbed and subtracting the ${ }^{15} \mathrm{~N}$ removed together with the ${ }^{15} \mathrm{~N}$ present in the stubble and macro roots as well as rhizodeposition at the time of the final sampling.

\subsection{Calculations}

All ${ }^{15} \mathrm{~N}$ enrichment values are given as excess relative to atmospheric $\mathrm{N}_{2}$ (at.\%-excess).

The proportion of absorbed ${ }^{15} \mathrm{~N}$ that was removed in harvested shoots was calculated on an annual basis for each of the two production years separately. 


\section{Results}

\subsection{Seasonal dry matter production and $N$ accumulation}

The plant communities that included actively $\mathrm{N}_{2}$-fixing legumes were growing well in both seasons, producing more that 1100 and $700 \mathrm{~g}$ dry matter per $\mathrm{m}^{2}$ per year where red and white clover was included, respectively (data not shown). Ryegrass in pure stand, on the other hand, only produced $210-230 \mathrm{~g}$ dry matter per $\mathrm{m}^{2}$ per year and contained 2.8 and $3.7 \mathrm{~g} \mathrm{~N} \mathrm{~m}^{-2}$ in the first and second growing season, respectively, confirming that the soil was indeed depleted in inorganic $\mathrm{N}$.

\subsection{Dry matter and nitrogen content in shoots, stubble, roots and rhizosphere at final harvest}

The combined dry matter yield of stubble and roots varied from $1085 \mathrm{~g} \mathrm{~m}^{-2}$ for pure stands of red clover to $558 \mathrm{~g} \mathrm{~m}^{-2}$ for ryegrass (Table 1). The red clover-ryegrass and white clover-ryegrass mixtures contained 16 and 30\% less dry matter in stubble and macro roots, respectively, than did the corresponding pure clover stands. The red cloverryegrass mixture was totally dominated by the clover component, constituting 90 and $94 \%$ of the shoot and stubble biomass, respectively, while white clover only contributed 30 and $36 \%$ to the corresponding yields of the white clover-ryegrass mixture (data not shown).
The $\mathrm{N}$ content of the stubble plus macro roots in the pure stands of red clover, white clover and ryegrass was 30.7, 27.7 and $8.2 \mathrm{~g} \mathrm{~N} \mathrm{~m}^{-2}$, respectively (Table 3 ). As was the case for the dry matter yields, the mixtures accumulated less $\mathrm{N}$ than the pure clover stands, 25 and 50\%, respectively, for the red clover-ryegrass and white clover-ryegrass combinations (Table 2). The $\mathrm{N}$ content of the stubble exceeded that of the macro roots with more than $50 \%$ in all cases except the red clover-ryegrass mixture, where the difference was less pronounced (17\%). These values demonstrate that stubble is a very important residue in the agroecosystems.

\section{3. ${ }^{15} \mathrm{~N}$ leaf labelling}

Leaf feeding with ${ }^{15} \mathrm{~N}$-labelled urea succeeded in a high ${ }^{15} \mathrm{~N}$ enrichment of all plants (Fig. 1). The obtained labelling efficiency varied with the climatic conditions and the dry warm weather promoting rapid absorption. The ${ }^{15} \mathrm{~N}$ enrichment also varied with the actual $\mathrm{N}$ accumulation rate of the plant that was offered ${ }^{15} \mathrm{~N}$ (Fig. 1). Consequently, high ${ }^{15} \mathrm{~N}$ enrichments of ryegrass were obtained in the middle of each growing season when the growth rate was low.

Calculating the total balance for the ${ }^{15} \mathrm{~N}$ administered over the two growing seasons demonstrated a high recovery ( $\geq 83 \%$ ) for the mixtures, whereas it only was $63-71 \%$ for species growing in pure stands (Table 3 ). The reason for the lower recoveries in pure stand plant communities is unknown. The ${ }^{15} \mathrm{~N}$ balance further showed that between

Table 1

Dry matter yields $\left(\mathrm{g} \mathrm{m}^{-2}\right)$ of shoots, stubble and macro-roots at the final harvest (means $\pm \mathrm{SE} ; n=4$ in pure stands and $n=8$ in mixtures)

\begin{tabular}{lllllll}
\hline & Shoots above $5 \mathrm{~cm}$ & Stubble below $5 \mathrm{~cm}$ & Macro roots 0-10 cm & Macro roots 10-20 cm & Macro roots 20-40 cm & Macro roots 40-60 cm \\
\hline RC-RG $^{\text {a }}$ & $925(60)$ & $428(23)$ & $237(20)$ & $106(13)$ & $64(7)$ & $74(1)$ \\
WC-RG $^{\text {b }}$ & $196(13)$ & $317(23)$ & $174(12)$ & $47(6)$ & $49(2)$ & $44(3)$ \\
RC (PS) & $650(128)$ & $612(264)$ & $240(29)$ & $88(7)$ & $73(2)$ & $72(5)$ \\
WC (PS) & $167(16)$ & $520(109)$ & $211(26)$ & $59(5)$ & $59(3)$ & $58(3)$ \\
RG (PS) & $89(18)$ & $266(50)$ & $160(32)$ & $47(3)$ & $42(5)$ & $43(3)$ \\
\hline
\end{tabular}

\footnotetext{
${ }^{a}$ Red clover-ryegrass.

${ }^{\mathrm{b}}$ White clover-ryegrass.

${ }^{c}$ Red clover in pure stand.

${ }^{\mathrm{d}}$ White clover in pure stand.

${ }^{\mathrm{e}}$ Ryegrass pure in stand.
}

Table 2

Nitrogen content $\left(\mathrm{g} \mathrm{m}^{-2}\right)$ in shoots stubble and macro-roots at the final harvest (means $\pm \mathrm{SE} ; n=4$ in pure stands and $n=8$ in mixtures)

\begin{tabular}{|c|c|c|c|c|c|c|}
\hline & Shoots above $5 \mathrm{~cm}$ & Stubble below $5 \mathrm{~cm}$ & Macro roots $0-10 \mathrm{~cm}$ & Macro roots $10-20 \mathrm{~cm}$ & Macro roots $20-40 \mathrm{~cm}$ & Macro roots $40-60 \mathrm{~cm}$ \\
\hline $\mathrm{RC}-\mathrm{RG}^{\mathrm{a}}$ & $20.7(1.7)$ & $12.3(0.6)$ & $5.7(0.5)$ & $2.3(0.3)$ & $1.3(0.1)$ & $1.3(0.1)$ \\
\hline $\mathrm{WC}-\mathrm{RG}^{\mathrm{b}}$ & $5.2(0.4)$ & $8.1(0.6)$ & $3.0(0.2)$ & $0.7(0.1)$ & $0.6(0.1)$ & $0.5(0.1)$ \\
\hline $\mathrm{RC}(\mathrm{PS})^{\mathrm{c}}$ & $13.3(0.8)$ & $19.2(2.8)$ & $6.3(0.7)$ & $2.1(0.1)$ & $1.6(0.0)$ & $1.5(0.1)$ \\
\hline $\mathrm{WC}(\mathrm{PS})^{\mathrm{d}}$ & $5.8(0.5)$ & $16.9(3.1)$ & $6.7(1.3)$ & $1.6(0.2)$ & $1.3(0.1)$ & $1.2(0.1)$ \\
\hline $\mathrm{RG}(\mathrm{PS})^{\mathrm{e}}$ & $1.9(0.3)$ & $5.4(1.0)$ & $1.8(0.1)$ & $0.4(0.1)$ & $0.3(0.1)$ & $0.3(0.0)$ \\
\hline
\end{tabular}

\footnotetext{
${ }^{a}$ Red clover-ryegrass.

${ }^{\mathrm{b}}$ White clover-ryegrass.

${ }^{c}$ Red clover in pure stand.

${ }^{\mathrm{d}}$ White clover in pure stand.

${ }^{\mathrm{e}}$ Ryegrass pure in stand.
} 


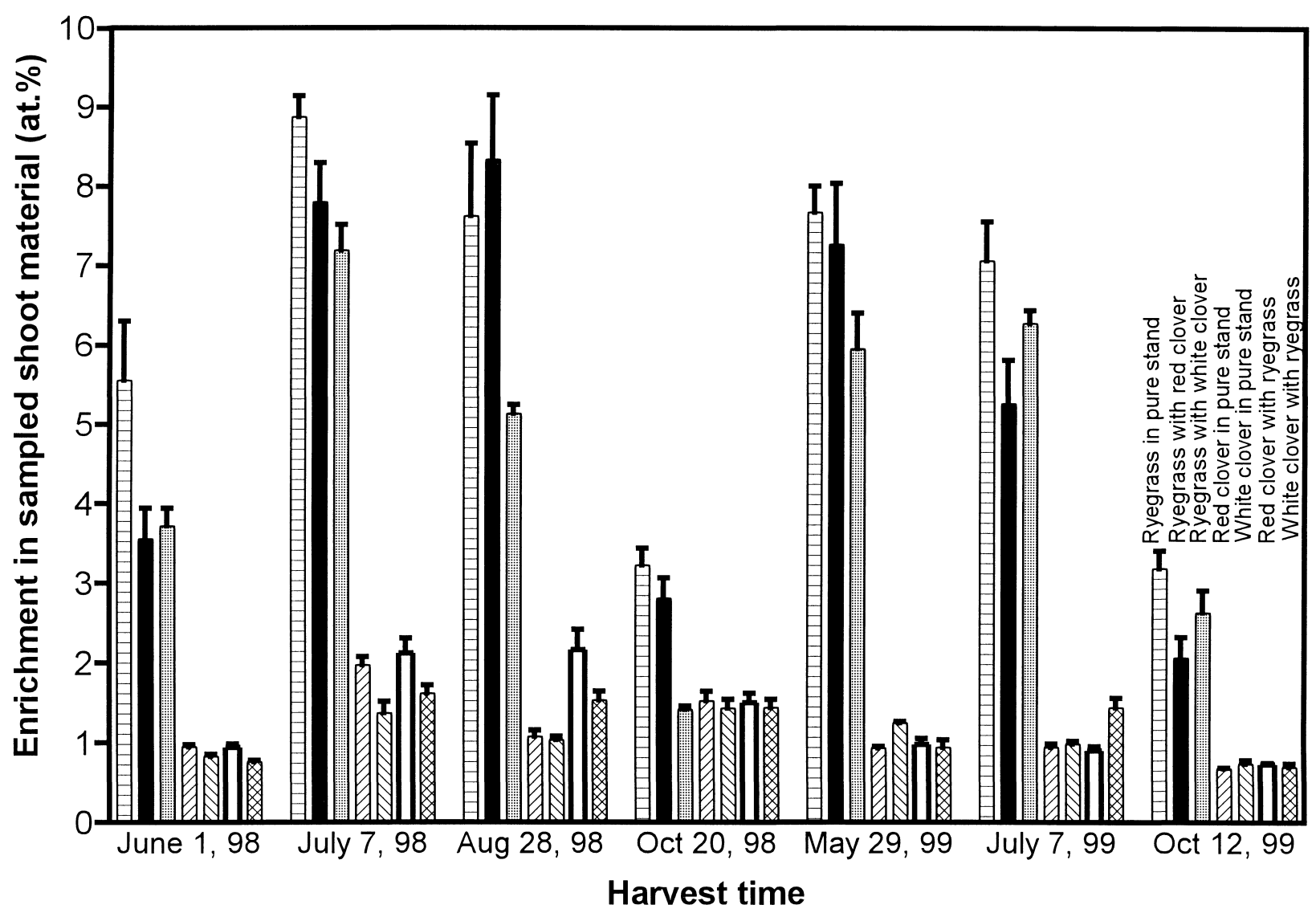

Fig. $1 .{ }^{15} \mathrm{~N}$-enrichment of shoot material during the two growing seasons of white clover, red clover and ryegrass growing in mixtures or pure stands over two

10 and $50 \%$ of the absorbed ${ }^{15} \mathrm{~N}$ was recovered in the harvested shoot material (Fig. 2). The variation between years was small except for the ${ }^{15} \mathrm{~N}$-labelled red or white clover that had a greater proportion of the absorbed ${ }^{15} \mathrm{~N}$ removed with harvested shoots in the first than in the second production year (Fig. 2). In all other cases, the differences between the plant communities were significantly greater than the differences between years.

The ${ }^{15} \mathrm{~N}$ cross-labelling of both plant species in the mixtures clearly revealed that labelled white clover growing in a mixture with ryegrass retained the absolute greatest proportion of the absorbed ${ }^{15} \mathrm{~N}$. Importantly, the roots were relatively uniformly labelled except for ryegrass in pure stands, where the enrichment of the roots below $40 \mathrm{~cm}$ decreased rapidly. It must be noted that the measured enrichment of the roots of the mixtures was an average of the labelled and unlabelled species (Table 4) and the enrichment of roots from corresponding species in pure stands was used for calculating the rhizodeposition.

\subsection{Rhizodeposition in rhizosphere soil and bulk soil}

The proportion of the $\mathrm{N}$ in the soil that derived from rhizodeposition (\%Ndfr) differed significantly between plant communities and between topsoil and deeper lying soil (Fig. 3). In pure stands of red and white clover and in

Table 3

Total balance of ${ }^{15} \mathrm{~N}$ applied via leaf feeding to different grassland species growing in pure stands or mixtures over two growing seasons (means \pm SE; $n=4$ )

\begin{tabular}{lccr}
\hline & ${ }^{15} \mathrm{~N}$ absorbed $\left(\mathrm{mg} \mathrm{mezotron}^{-1}\right)$ & ${ }^{15} \mathrm{~N}$ recovered $\left(\mathrm{mg} \mathrm{mezotron}^{-1}\right)$ & ${ }^{15} \mathrm{~N}$ unaccounted $(\%)$ \\
\hline${ }^{15} \mathrm{~N}-$ RC w RG & \\
${ }^{15} \mathrm{~N}-$ WC w RG & $131(11)$ & $111(13)$ & $15(6)$ \\
${ }^{15} \mathrm{~N}-$ RG w RC & $97(10)$ & $81(5)$ & $3(5)$ \\
${ }^{15} \mathrm{~N}-$ RG w WC & $82(3)$ & $78(3)$ & $11(4)$ \\
${ }^{15} \mathrm{~N}-$ RC (PS) & $89(3)$ & $79(4)$ & $37(7)$ \\
${ }^{15} \mathrm{~N}$-WC (PS) & $135(10)$ & $85(11)$ & $34(7)$ \\
${ }^{15} \mathrm{~N}-$ RG (PS) & $111(7)$ & $62(5)$ & $29(6)$ \\
\hline
\end{tabular}

${ }^{\text {a }}{ }^{15} \mathrm{~N}$-labelled red clover with ryegrass; ${ }^{15} \mathrm{~N}$-labelled white clover with ryegrass; ${ }^{15} \mathrm{~N}$-labelled ryegrass with white clover; ${ }^{15} \mathrm{~N}$-labelled red clover in pure stand; ${ }^{15} \mathrm{~N}$-labelled white clover in pure stand; ${ }^{15} \mathrm{~N}$-labelled ryegrass in pure stand. 


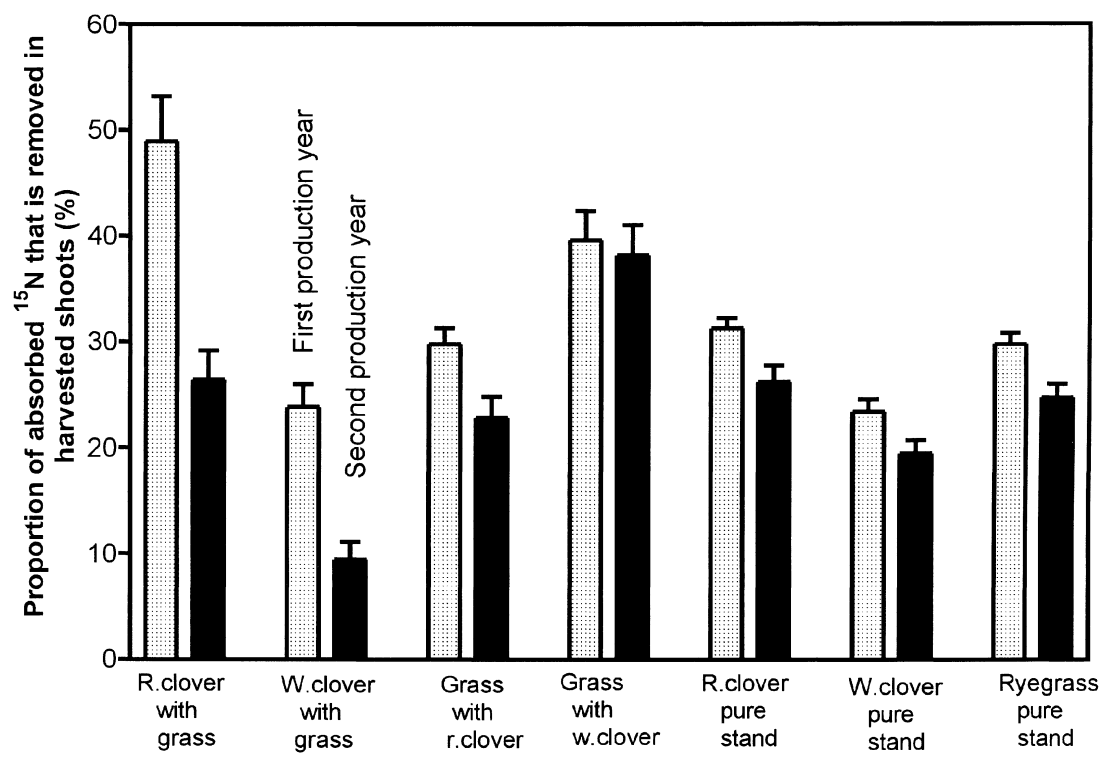

Fig. 2. Proportion of ${ }^{15} \mathrm{~N}$ absorbed via leaf-feeding that subsequently was removed in harvested shoots of white clover, red clover and ryegrass growing in mixtures or pure stands over two complete growing seasons (means $\pm \mathrm{SE} ; n=4$ ).

Table 4

Average enrichment ( at.\%) of isolated macro roots at the final sampling. The ${ }^{15} \mathrm{~N}$ enrichment of the roots of plants growing in mixtures is an average of the labelled and the unlabelled species as they cannot be separated (means; $n=4$ ). Coefficients of variations were on average $9.6 \%$ and never exceeded $20 \%$

\begin{tabular}{|c|c|c|c|c|}
\hline & $0-10 \mathrm{~cm}$ depth & $10-20 \mathrm{~cm}$ depth & $20-40 \mathrm{~cm}$ depth & $40-60 \mathrm{~cm}$ depth \\
\hline${ }^{15} \mathrm{~N}-\mathrm{RC}$ w $\mathrm{RG}^{\mathrm{a}}$ & 0.6910 & 0.6201 & 0.5934 & 0.5944 \\
\hline${ }^{15} \mathrm{~N}-\mathrm{WC}$ w RG & 0.9884 & 0.9590 & 0.9854 & 0.9396 \\
\hline${ }^{15} \mathrm{~N}-\mathrm{RG}$ w RC & 0.6535 & 0.5629 & 0.5078 & 0.5195 \\
\hline${ }^{15} \mathrm{~N}-\mathrm{RG}$ w WC & 1.0486 & 1.0184 & 1.0184 & 0.8663 \\
\hline${ }^{15} \mathrm{~N}-\mathrm{RC}(\mathrm{PS})$ & 0.7181 & 0.6402 & 0.6036 & 0.6465 \\
\hline${ }^{15} \mathrm{~N}-\mathrm{WC}(\mathrm{PS})$ & 0.9343 & 0.8712 & 0.8443 & 0.8157 \\
\hline${ }^{15} \mathrm{~N}-\mathrm{RG}(\mathrm{PS})$ & 2.3740 & 2.2029 & 1.6760 & 1.6238 \\
\hline
\end{tabular}

${ }^{a}{ }^{15} \mathrm{~N}$-labelled red clover with ryegrass; ${ }^{15} \mathrm{~N}$-labelled white clover with ryegrass; ${ }^{15} \mathrm{~N}$-labelled ryegrass with white clover; ${ }^{15} \mathrm{~N}$-labelled red clover in pure stand; ${ }^{15} \mathrm{~N}$-labelled white clover in pure stand; ${ }^{15} \mathrm{~N}$-labelled ryegrass in pure stand.

Table 5

Deposition of $\mathrm{N}\left(\mathrm{g} \mathrm{m}^{-2}\right)$ in the rhizosphere and bulk soil of different grassland species growing in mixtures or pure stands $(\mathrm{means} \pm \mathrm{SE} ; n=4)$

\begin{tabular}{lcccc}
\hline & $0-10$ cm depth & $10-20$ cm depth & $20-40$ cm depth & $40-60 \mathrm{~cm}$ depth \\
\hline${ }^{15} \mathrm{~N}-$ RC w RG & $22.8(9.2)$ & $1.7(0.2)$ & $1.0(0.8)$ & $0.8(0.1)$ \\
${ }^{15} \mathrm{~N}-$ WC w RG & $8.1(3.9)$ & $3.9(1.6)$ & $0.7(0.2)$ & $0.4(0.1)$ \\
${ }^{15} \mathrm{~N}-$ RG w RC & $42.9(10.4)$ & $14.8(2.1)$ & $2.6(1.6)$ & $2.7(2.0)$ \\
${ }^{15} \mathrm{~N}-$ RG w WC & $19.0(3.7)$ & $10.7(1.7)$ & $0.2(0.4)$ & $0.8(0.3)$ \\
${ }^{15} \mathrm{~N}-$ RC (PS) & $52.1(7.2)$ & $5.6(0.7)$ & $1.8(0.4)$ & $1.1(3.0)$ \\
${ }^{15} \mathrm{~N}-$ WC (PS) & $61.5(14.9)$ & $1.8(0.3)$ & $0.6(0.2)$ & $0.3(0.6)$ \\
${ }^{15} \mathrm{~N}-$ RG (PS) & $6.7(1.4)$ & $0.3)$ & \\
\hline
\end{tabular}

${ }^{a}{ }^{15} \mathrm{~N}$-labelled red clover with ryegrass; ${ }^{15} \mathrm{~N}$-labelled white clover with ryegrass; ${ }^{15} \mathrm{~N}$-labelled ryegrass with white clover; ${ }^{15} \mathrm{~N}$-labelled red clover in pure stand; ${ }^{15} \mathrm{~N}$-labelled white clover in pure stand; ${ }^{15} \mathrm{~N}$-labelled ryegrass in pure stand.

ryegrass growing in association with red clover more than $20 \%$ of the soil $\mathrm{N}$ in the top $10 \mathrm{~cm}$ soil layer derived from rhizodeposition. The corresponding value for the other plant communities was 3-7\% (Fig. 3).

The quantity of $\mathrm{N}$ deposited over the 2 years, i.e. the product of \% Ndfr and soil $\mathrm{N}$ content, amounted to 65$70 \mathrm{~g} \mathrm{~m}^{-2}$ in the pure stands of red and white clover. Assum- ing the N-rhizodeposits estimated from cross-labelling of either of the two species in the mixtures to be additive, the total amount of $\mathrm{N}$ deposited by red clover-ryegrass and white clover-ryegrass mixtures amounted to 89 and $32 \mathrm{~g} \mathrm{~m}^{-2}$, respectively (Table 5). This deposition occurred predominantly in the top $10 \mathrm{~cm}$ soil layer.

The amount of the rhizodeposited $\mathrm{N}$ that remained in the 


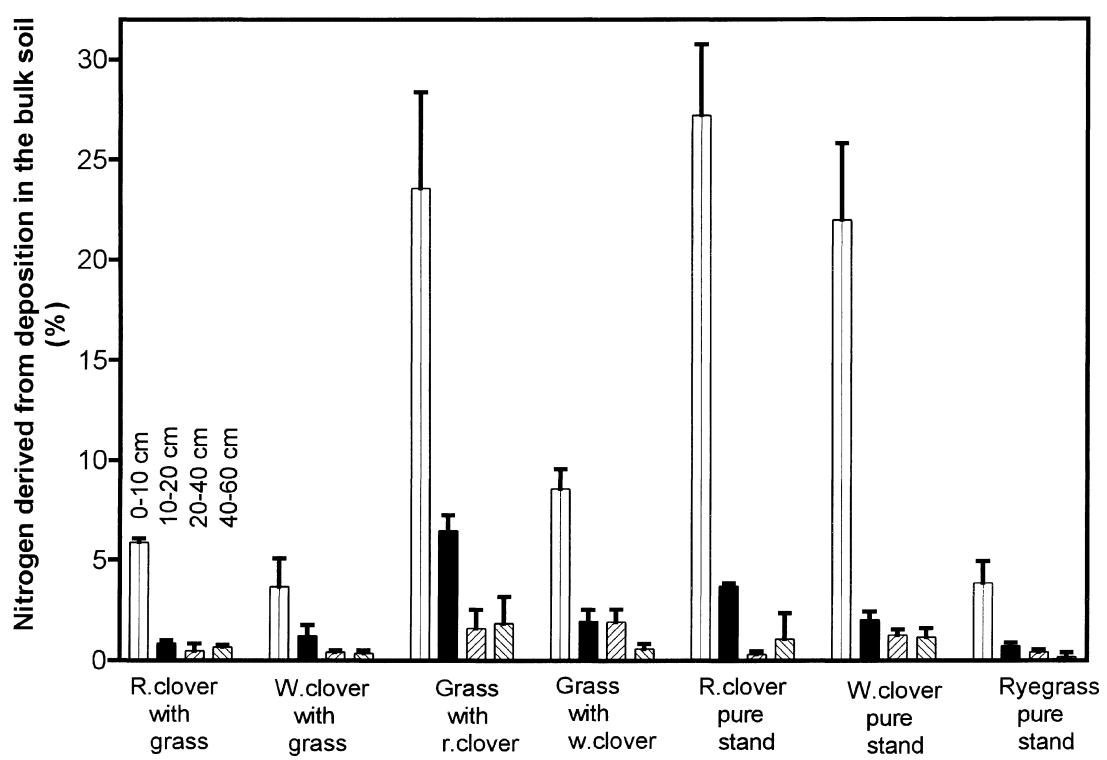

Fig. 3. Rhizodeposition of $\mathrm{N}$ in proportion of total soil $\mathrm{N}$ (bulk and rhizosphere) below white clover, red clover and ryegrass growing in mixtures or pure stands over two complete growing seasons (means $\pm \mathrm{SE} ; n=4$ ).

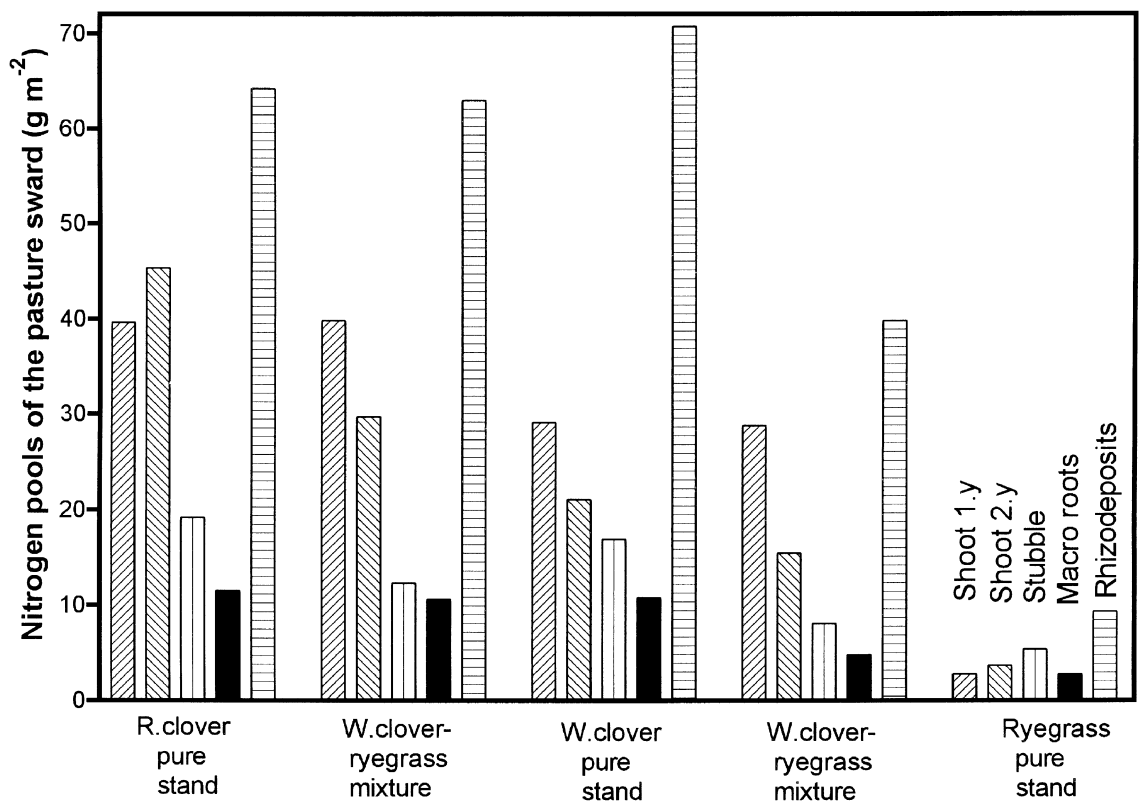

Fig. 4. Total nitrogen content of harvested shoots, stubble, macro roots and rhizodeposits of white clover, red clover and ryegrass growing in mixtures or pure stands over two complete growing seasons (means $\pm \mathrm{SE} ; n=4$ for pure stands, $n=8$ for mixtures).

root-adhering soil only constituted a significant proportion of the total $\mathrm{N}$ deposition in the top 10-cm soil layer (data not shown). Here, the rhizosphere soil contained 12 and $15 \%$ of the $\mathrm{N}$ deposited by ryegrass in mixture with white clover and ryegrass in pure stands, respectively. In all other cases, the amount of rhizodeposited $\mathrm{N}$ remaining in the root-adhering soil did not exceed $3.5 \%$.

\subsection{The role of rhizodeposition in the $N$ economy of the sward}

Rhizodeposition constituted in all plant communities
$80-87 \%$ of the total below-ground plant-derived N (Fig. 4). In the mixtures of red clover-ryegrass and white cloverryegrass and the pure stands of red clover, white clover and ryegrass, respectively, the rhizodeposition constituted a 1.05 , $1.52,1.26,2.21$ and 2.77 fold increase over the total harvested shoot $\mathrm{N}$ during the two production years (Fig. 4).

\section{Discussion}

Using a ${ }^{15} \mathrm{~N}$ leaf labelling approach directly on plants growing in the field the present work demonstrates that 
rhizodeposition of $\mathrm{N}$ makes a very significant contribution to the $\mathrm{N}$ input in grasslands. In fact, rhizodeposition of $\mathrm{N}$ may even substantially exceed the amount of $\mathrm{N}$ removed by harvest of above-ground plant parts (Fig. 4). Expressed relative to the quantity of $\mathrm{N}$ recovered in macro roots, the rhizodeposition was in all cases more than 5-fold higher (Fig. 4). Not only rhizodeposition, but also stubble, using a cutting height of $5 \mathrm{~cm}$, constituted a significant $\mathrm{N}$ pool, highlighting the importance of this fraction for the $\mathrm{N}$ dynamics in grasslands.

\section{1. ${ }^{15} \mathrm{~N}$ leaf labelling}

The present use of the direct ${ }^{15} \mathrm{~N}$ leaf labelling approach for assessing $\mathrm{N}$ rhizodeposition is based on two assumptions: (i) the ${ }^{15} \mathrm{~N}$ enrichment of the $\mathrm{N}$ compounds deposited is assumed to be identical to that of the macro roots; and (ii) the ${ }^{15} \mathrm{~N}$ enrichment of the soil $\mathrm{N}$ is accurately reflected in the ${ }^{15} \mathrm{~N}$ enrichment of a non-leguminous crop.

Regarding the first assumption, the contribution of the ${ }^{15} \mathrm{~N}$ to the total $\mathrm{N}$ content of particularly the legumes was minimal (Tables 2 and 3) and the labelling procedure resulted in a fairly uniform ${ }^{15} \mathrm{~N}$ enrichment of shoots (Høgh-Jensen and Schjoerring, 2000) and macro roots in various depths (Table 4), indicating that the ${ }^{15} \mathrm{~N}$ label was distributed relatively uniformly between all tissue and organs. Furthermore, the enrichment of the clover shoots was rather constant on a seasonal basis, while that of grass declined towards the end of each growing season (Fig. 1). Thus, \%Ndfr may have been overestimated for grass, but not for legumes.

As regards the second assumption, the bioassay of ${ }^{15} \mathrm{~N}$ enrichment of the soil-borne $\mathrm{N}$ is, even under relative undisturbed conditions, considered only to give an approximate value (see, e.g. Handley and Scrimgeour, 1997). However, even a $50 \%$ change in the estimate of the ${ }^{15} \mathrm{~N}$ enrichment of the soil would only marginally change the estimates of $\mathrm{N}$ rhizodeposition. Furthermore, the fact that the estimated $\mathrm{N}$ rhizodeposition declined with depth in the soil profile and was very small in the deeper soil layers (Table 5) suggests that the procedure we used gave realistic results.

\subsection{Input of residues}

We removed visible root fragments by hand without any washing procedure. The recorded dry matter and $\mathrm{N}$ root yields of the ryegrass and clover species (Table 1) slightly exceeded yields of roots isolated from soil by wet-sieving under otherwise comparable experimental conditions (Haugaard-Nielsen et al., 1998; Høgh-Jensen et al., 1998). However, estimates of mature root biomass obtained by wet-sieving must be questioned due to the fragility of roots and due to the fact that fine roots, root hairs and partly or fully decomposed root materials are not retained in the wet-sieving procedure (Sauerbeck and Johnen, 1976; Unkovich et al., 1994). In addition to the lack of retention of such high quality root material, water-soluble compounds will also be lost from roots during wet-sieving, leading to lower concentrations of $\mathrm{N}$ in the recovered roots.

\subsection{Rhizodeposition}

Following deposition, some of the $\mathrm{N}$ will be stabilised in accordance with the theory of turnover of soil organic matter following a series of first-order reactions (Paul and Juma, 1981). This stabilised fraction is the one subsequently determined as deriving from rhizodeposition. The fraction that is not stabilised is subject to: (i) loss; (ii) re-absorption by the plant it originated from; or (iii) transfer to associated plant species (Høgh-Jensen and Schjoerring, 2000).

Even the N-deficient ryegrass plants growing in association with red clover or white clover contributed to a considerable $\mathrm{N}$ rhizodeposition (Figs. 3 and 4). Consequently, rhizodeposition can be viewed a net process where the $\mathrm{C}$ and the $\mathrm{N}$ input to the system may determine the amount of $\mathrm{N}$ that is immobilised in agreement with the rapid daily turnover of a relatively large pool of inorganic $\mathrm{N}$ below grassland (Ledgard et al., 1998).

Previous studies on $\mathrm{N}$ rhizodeposition have mainly been carried out using pure stands of plants grown for a relatively short period under controlled conditions in solution culture, pots or soil columns. Under such conditions, the rhizodeposition of $\mathrm{N}$ amounted to approx. $30 \%$ of the total belowground plant-derived $\mathrm{N}$ in 3-month-old maize (Hétier et al., 1986) and, for mature plants, 46-48\% in pea (Jensen, 1996; Sawatsky and Soper, 1991), 71\% in barley (Sawatsky and Soper, 1991), 16-19\% in wheat (Janzen, 1990; Janzen and Bruinsma, 1989; Janzen and Bruinsma, 1993) and 65\% in lupin (Russell and Fillery, 1996b). Due to differences in rooting volume these values cannot be directly transferred to the field situation. Nevertheless, our estimates of field $\mathrm{N}$ rhizodeposition amounting to $80-87 \%$ of total belowground plant-derived $\mathrm{N}$ (Fig. 4) agree reasonably well with the above-mentioned studies, also taking into account that a considerably longer period was covered. It agrees especially with the estimates of Russell and Fillery (1996b) who used soil columns. During two complete seasons of plants growing in a low fertility soil, the fine roots may turnover several times (Dubach and Russelle, 1994) and consequently contribute substantially to the deposition.

\subsection{Turnover of plant-derived $N$ in the soil}

The ${ }^{15} \mathrm{~N}$ cross-labelling approach revealed that ${ }^{15} \mathrm{~N}$ labelled white clover growing in mixture with ryegrass retained the absolute greatest proportion of the absorbed ${ }^{15} \mathrm{~N}$ (Fig. 2). In addition, the amount of ${ }^{15} \mathrm{~N}$ that was found in the stubble material at the end of the second growing season exceeded that removed in harvested shoots during one season (data not shown).

Studies of plant residue decomposition have often used macro roots as representing root material (e.g. Ladd and Amato, 1986). However, this approach will not give a 
correct picture of the $\mathrm{N}$ turnover following ploughing-in of the grass sward due to differences in the quality of macro roots and that of rhizodeposited compounds (Jensen, 1996). Furthermore, the mass of macro roots isolated by wet-sieving or by hand picking underestimates the true input and will therefore not allow a correct prediction of crop rotational effects of grass swards (Høgh-Jensen, 1999). There is consequently a need for supplementing the empirical evaluations (Johnston et al., 1994; Haynes, 1999) with further studies of the quality of rhizodeposited $\mathrm{N}$ compounds and N-containing tissues.

Even N-deficient ryegrass growing in pure stand had a very substantial rhizodeposition of $\mathrm{N}$ expressed relatively to the $\mathrm{N}$ content of harvested shoots, stubble and macro roots (Fig. 4). This was the case despite a general high C-to-N ratio in grass tissue compared to clover and implies that the turnover of grass roots or excretion of $\mathrm{N}$ compounds from grass roots are higher than from red or white clover roots, in agreement with unpublished results by Andreas de Neergaard (pers. commun.) who, using ${ }^{14} \mathrm{CO}_{2}$ leaf labelling, found ryegrass to be the carbon donor when growing in mixtures with white clover. Ryegrass is well known for having a higher density and length of root hairs compared with clovers (e.g. Caradus, 1980). However, Dubach and Russelle (1994) found the turnover of fine roots and nodules in alfalfa to be high.

\subsection{Conclusions}

Our findings demonstrate the very important, but long unrecognised, role that rhizodeposition plays in the $\mathrm{N}$ economy of grassland. Thus, $\mathrm{N}$ rhizodeposition even exceeded the amount of $\mathrm{N}$ that was harvested in shoot material over two complete growing seasons for all communities. The $\mathrm{N}$ deposition also exceeded the amount of $\mathrm{N}$ contained in stubble and roots.

Expressed relative to the total amount of $\mathrm{N}$ in shoots, stubble and macro roots at the final harvest, the rhizodeposited compounds constituted $68,70,56,91$ and $64 \%$ of the $\mathrm{N}$ in the mixtures of red clover-grass and white clover-grass and the pure stands of red clover, white clover and ryegrass, respectively. The corresponding values for $\mathrm{N}$ rhizodeposition relative to total below-ground $\mathrm{N}$ were $80,83,85,87$ and $80 \%$. Thus, the rhizodeposited compounds constituted by far the dominant pool of the plant-derived $\mathrm{N}$ in the soil.

The average contribution of fixed $\mathrm{N}_{2}$ to total shoot $\mathrm{N}$ content as determined in plots adjacent to the mezotrons was for both red and white clover 92 and $95 \%$ in the first and second production year, respectively. In the pure stand of red clover it was $90 \%$ and in pure stands of white clover it was $84 \%$. The major part of the deposited $\mathrm{N}$ would consequently derive from the atmosphere and as such exceed the amount of atmospheric-derived $\mathrm{N}$ in the harvested shoots. This very significant contribution must be taken into account when assessing the contribution of biological $\mathrm{N}_{2}$ fixation to the $\mathrm{N}$ balance of terrestrial ecosystems.

\section{Acknowledgements}

Financial support from the Danish Agricultural Research Centre for Organic Farming is gratefully acknowledged. Further, the dedicated work of Mr Vagn Petersen in root isolation is much appreciated.

\section{References}

Böhm, W., 1979. Methods for Studying root systems. Ecological Studies, vol. 33. Springer, New York (188pp.).

Caradus, J.R., 1980. Distinguishing between grass and legume species for efficiency of phosphorus use. New Zealand Journal of Agricultural Research 23, 75-81.

Cheng, W., Coleman, D.C., Carroll, C.R., Hoffman, C.A., 1993. In situ measurement of root respiration and soluble carbon concentrations in the rhizosphere. Soil Biology \& Biochemistry 25, 1189-1196.

Curl, E.A., Truelove, B., 1986. The Rhizosphere. Springer, Berlin (288pp.).

Dubach, M., Russelle, M.P., 1994. Forage legume roots and nodules and their role in nitrogen transfer. Agronomy Journal 86, 259-266.

Gee, G.W., Bauder, J.W., 1986. Particle-size analysis. In: Klute, A. (Ed.). Methods of Soil Analysis. Part 1, 2nd ed. ASA, Madison, Wisconsin, pp. 545-567.

Handley, L.L., Scrimgeour, S.M., 1997. Terrestrial plant ecology and ${ }^{15} \mathrm{~N}$ natural abundance: the present limits to interpretation for uncultivated systems with original data from a Scottish old field. Advances in Ecological Research 27, 133-212.

Haugaard-Nielsen, H., Neergaard, A.de, Jensen, L.S., Høgh-Jensen, H., Magid, J., 1998. A field study of nitrogen dynamics and spring barley growth as affected by the quality of incorporated residues from white clover and ryegrass. Plant and Soil 203, 91-101.

Haynes, R.J., 1999. Labile organic matter fractions and aggregate stability under short-term, grass-based leys. Soil Biology \& Biochemistry 31, $1821-1830$.

Hétier, J.M., Andreux, F., Schouller, E., Marol, C., 1986. Organic matter inputs to soil after growth of carbon-14-nitrogen-15 labelled maize. Soil Science Society of America Journal 50, 76-80.

Hood, R.C., Goran, K.N., Aigner, M., Harderson, G., 1999. A comparison of direct and indirect ${ }^{15} \mathrm{~N}$ techniques for estimating crop $\mathrm{N}$ uptake from organic residues. Plant and Soil 208, 259-270.

Høgh-Jensen, H., Schjoerring, J.K., 1997. Residual nitrogen effect of clover-ryegrass swards on yield and $\mathrm{N}$ uptake of a subsequent winter wheat crop as studied by use of ${ }^{15} \mathrm{~N}$ methodology and mathematical modelling. European Journal of Agronomy 6, 235-243.

Høgh-Jensen, H., Schjoerring, J.K., 2000. Below-ground nitrogen transfer between different grassland species: direct quantification by ${ }^{15} \mathrm{~N}$ leaf feeding compared with indirect dilution of soil ${ }^{15} \mathrm{~N}$. Plant and Soil 225 , $13-25$.

Høgh-Jensen, H., Loges, R., Jensen, E.S., Jørgensen, F.V., Vinther, F.P., 1998. Empirisk model til kvantificering af symbiotisk kvælstoffiksering i bælgplanter (in Danish). In: Kristensen, E.S., Olesen, J.E. (Eds.). Kvælstofudvaskning og -balancer i konventionelle og økologiske produktionssystemer, Forskningscenter for Økologisk Jordbrug, Foulum, Denmark, pp. 69-86.

Høgh-Jensen, H., 1999. An optimal proportion of green fallow in stockless farming systems: grain yield, nitrogen leaching and soil organic matter. In: Olesen, J.E., Eltun, R., Gooding, M.J., Jensen, E.S., Köpke, U. (Eds.). Designing and Testing Crop Rotations for Organic Farming, Danish Research Centre for Organic Farming, Report no. 1, pp. 223-234.

Janzen, H.H., 1990. Deposition of nitrogen into the rhizosphere by wheat roots. Soil Biology \& Biochemistry 22, 1155-1160.

Janzen, H.H., Bruinsma, Y., 1989. Methodology for the quantification of root and rhizosphere nitrogen dynamics by exposure of shoots to ${ }^{15} \mathrm{~N}$ labelled ammonia. Soil Biology \& Biochemistry 21, 189-196. 
Janzen, H.H., Bruinsma, Y., 1993. Rhizosphere N deposition by wheat under varied water stress. Soil Biology \& Biochemistry 25, 631-632.

Jensen, E.S., 1996. Rhizodeposition of $\mathrm{N}$ by pea and barley and its effect on soil N dynamics. Soil Biology \& Biochemistry 28, 65-71.

Johnston, E., McEwen, J., Lane, P.W., Hewitt, M.V., Poulton, P.R., Yeoman, D.P., 1994. Effects of one to six year old ryegrass-clover leys on soil nitrogen and on the subsequent yields and fertilizer nitrogen requirements of the arable sequence winter wheat, potatoes, winter wheat, winter beans (Vicia faba) grown on a sandy loam soil. Journal of Agricultural Science 122, 73-89.

Ladd, J.N., Amato, M., 1986. The fate of nitrogen from legume and fertilizer sources in soils successively cropped with wheat under field conditions. Soil Biology \& Biochemistry 18, 417-425.

Ledgard, S.F., Freney, J.R., Simpson, J.R., 1985. Assessing nitrogen transfer from legumes to associated grasses. Soil Biology \& Biochemistry $17,575-577$.

Ledgard, S.F., Jarvis, S.C., Hatch, D.J., 1998. Short-term nitrogen fluxes in grassland soils under different long-term nitrogen management regimes. Soil Biology \& Biochemistry 30, 1233-11241.

Lory, J.A., Russelle, M.P., Heichel, G.H., 1992. Quantification of symbiotically fixed nitrogen in soil surrounding alfalfa roots and nodules. Agronomy Journal 84, 1033-1040.

McNeill, A.M., Zhu, C., Fillery, I.R.P., 1997. Use of in situ ${ }^{15} \mathrm{~N}$-labelling to estimate the total below-ground nitrogen of pasture legumes in intact soilplant systems. Australian Journal of Agricultural Research 48, 295-304.

Olsen, S.R., Cole, C.V., Watanabe, F.S., Dean, L.A., 1954. Estimation of available phosphorus in soils by extraction with sodium bicarbonate. USDA Circular No. 939, 19.

Page, A.L., Miller, R.H., Keeney, D.R., 1982. Methods of soil analysis. Part 2. Chemical and Microbiological Properties. 2nd ed. ASA, Madison.

Palta, J.A., Fillery, I.R., Mathews, E.L., Turner, N.C., 1991. Leaf feeding of $\left({ }^{15} \mathrm{~N}\right)$ urea for labelling wheat with nitrogen. Australian Journal of Plant Physiology 18, 627-636.

Paul, E.A., Juma, N.G., 1981. Mineralization and immobilization of soil nitrogen by microorganisms. In: Clark, F.E., Rosswall, T. (Eds.). Terrestrial Nitrogen Cycles Processes, Ecosystem Strategies and Management Impacts, Ecological Bulletins, vol. 33, pp. 179-195.

Rovira, A.D., Foster, R.C., Martin, J.K., 1979. Note on terminology: origin, nature and nomenclature of organic materials in the rhizosphere. In: Harley, J.L., Russell, R.S. (Eds.). The Soil-Root Interface, Academic Press, London, pp. 1-4.

Ruschel, A.P., Salati, E., Vose, P.B., 1979. Nitrogen enrichment of soil and plant by Rhizobium phaseoli-Phaseolus vulgaris symbiosis. Plant and Soil 51, 425-429.

Russell, C.A., Fillery, I.R.P., 1996a. In situ ${ }^{15} \mathrm{~N}$ labelling of lupin belowground biomass. Australian Journal of Agricultural Research 47, 10351046.

Russell, C.A., Fillery, I.R.P., 1996b. Estimates of lupin below-ground biomass nitrogen, dry matter, and nitrogen turnover to wheat. Australian Journal of Agricultural Research 47, 1047-1059.

Sauerbeck, D., Johnen, B., 1976. Umsatz von pflaanzenwurzeln in Laufe der vegetationsperiode und dessen beitrag zur bodenatmung. Zeitschrift fur Pflanzenernährung und Bodenkunde 139, 315-328.

Sawatsky, N., Soper, R.J., 1991. A quantitative measurement of the nitrogen loss from the root system of field pea (Pisum avense L.) grown in soil. Soil Biology \& Biochemistry 23, 255-259.

Ta, T.C., Faris, M.A., MacDowald, F.D.H., 1989. Evaluation of ${ }^{15} \mathrm{~N}$ methods to measure nitrogen transfer from alfalfa to companion timothy. Plant and Soil 114, 243-247.

Ta, T.C., MacDowald, F.D.H., Faris, M.A., 1979. Excretion of nitrogen assimilated from $\mathrm{N}_{2}$ fixed by nodulated roots of alfalfa (Medicago sativa). Canadian Journal of Botany 64, 2063-2067.

Unkovich, M.J., Pate, J.S., Hamblin, J., 1994. The nitrogen economy of broadacre lupin in south-west Australia. Australian Journal of Agricultural Research 45, 149-164.

Whipps, J.M., Lynch, J.M., 1985. Energy losses by the plant in rhizosphere. Annual Proceeding of the Phytochemical Society of Europe 26, 59-71. 